\title{
METHODS OF THE ESTIMATED TWO-PARAMETER LINEAR REGRESSION MODELSFOR DIAGNOSIS OF BRONCHIAL ASTHMA SEVERITY IN CHILDREN
}

\author{
PIHNASTYI OLEH MYKHAILOVYCH*1, KOZHYNA OLGA SERGEYEVNA ${ }^{2}$
}

1Department of distributed information systems and cloud technologies, National Technical University "Kharkiv Polytechnic Institute", Kharkov, Ukraine, 2Department of Fundamentals of Pediatrics No.2,Kharkiv National Medical University, Kharkiv, Ukraine. Email: pihnastyi@gmail.com

Received: 30 November 2020, Revised and Accepted: 22 December 2020

\begin{abstract}
Objectives: Prognostication of bronchial asthma severity in children by means of two-parameter regression models building.

Methods: A clinical study of 70 children with bronchial asthma diagnosis of 6 to 18 years old was done.142 factors were analyzed and a degree of relationship among them was revealed. Single-factor regression models were used during preliminary experimental data processing.

Results: The correlation connection between the value observed and the factors under research was revealed. The method of two-parameter linear models with a fair accuracy was developed.
\end{abstract}

Conclusion: The suggested method of approximate two-parameter linear regression models can be used for preliminary analysis of medical research data where the value observed depends on a big number of loosely connected factors.

Keywords: Asthma, Child, Regression model.

\section{INTRODUCTION}

Bronchial asthma (BA) is a heterogeneous inflammatory respiratory disease with more than 300 million people currently affected [1, 2] Despite years long studies asthma is still the most widespread chronic disease within pediatric population in different countries, and the disease incidence increases with each passing year [3, 4]. Patients' quality of life significantly decreases and is followed by tangible economic costs both for a family and for the society [5, 6, 7]. Notwithstanding a significant progress in the disease treatment, asthma still remains one of the most frequent reasons of invalidity in pediatrics [8, 9].Currently, not only the disease control but also revealing of pathogenetic connections and triggers for preventive activities planning are still remain relevant. Prediction of asthma onset and course in children is still difficult due to a multi factorial nature of disease [10].Early disease manifestation as well as similarity of clinical manifestations with other diseases of primary school age impede timely diagnosis [11-17]. If children with an undiagnosed BA get a long and improper treatment, preventive and therapy measures are placed on too late and it affects the quality of life of both a patient and their family[18,19]. Early detection of patients with a high risk of disease progressing allows to use individual therapy and observation methods and helps to provide reliable control of asthma. Regardless significant achievements in understanding of asthma genetics, ethiology and pathogenesis, there are still patients with severe course of asthma and poor disease control. Numerous clinical studies of uncontrolled asthma course prove the necessity of analyzing the factors causing strong forms of asthma [20-23].To increase the study quality, analyzing requires improving both the models themselves and methods of their building. Linear regression models area common method of severity of bronchial asthma diagnosis. Refinement of the results is possible by using regression models containing two or more factors. However, this approach leads to additional calculations in the amount nonlinearly depending on the number of factors. The complexity and laboriousness of linear multivariate models building result to the fact that the model data are used less often in the initial evaluation and analysis of data.

It is generally accepted that it is difficult to predict the severity of bronchial asthma due to influence of a large number of factors that are loosely connected. This particular fact allows to develop rather accurate and efficient evaluative multiple linear models for diagnosis of bronchial asthma severity.

In this paper, we propose a method of two-parameter linear models on the basis of pair wise regression models and estimate their error.

\section{METHODOLOGY}

The results of the study involving 90 children aged from 6 to 17 years 11 months and 29 days were used as a dataset for linear twoparameter regression models.70 children with diagnosed BA were included into the main group. The control group contained 20 healthy children. The average age of children with BA was $11.0 \pm 3.7$ years. The workup included the study of patients' parents complaints and medical and life history by means of interviewing patients' parents as well as clinical features of disease course and results of clinical and laboratory examinations in dynamics of the disease. The study was conducted with respect for human rights and international ethical requirements; it does not violate ethical norms in science and standards for conducting biomedical research.

The data were originated to build a regression model. The raw data from experimental studies are presented in Table 2. Individual patient data are encoded. Before the experiment, the factors that could influence on severity of bronchial asthma were determined [10]. These factors, with a total of 142, are divided into categories 
(Table 1) allowing to unify the data analysis and structure connections among them (Fig. 1 - Fig. 6).

Table: 1 Classification of factors

\begin{tabular}{|c|c|c|}
\hline & & \\
\hline id & Description & Common Information \\
\hline 1 & Course type & Severe persistent, Moderate persistent, Mild persistent,Intermittent \\
\hline 2 & $\begin{array}{l}\text { Principal diagnosis(case } \\
\text { taking) }\end{array}$ & Atopic dermatitis, Allergic rhinitis, Deflection of nasal septum, Secondary cardiomyopathy \\
\hline 3 & Anamnesis of disease & Number of years from the first symptoms \\
\hline 4 & Anamnesis of life & $\begin{array}{l}\text { Bronchial asthma in mother, Bronchial asthma in father, Allergic rhinitis in mother, Allergic } \\
\text { rhinitis in father, Bronchial asthma in relatives of second generation }\end{array}$ \\
\hline 5 & Complete blood count & $\begin{array}{l}\text { RBC, HBC, WBC, Eosinophils \%, Basophils \%, Band neutrophils \%, Segmented neutrophils \%, } \\
\text { Lymphocytes \%, Monocytes \%, ESR }\end{array}$ \\
\hline 6 & Urinalysis Test & Color, Appearance, Specific gravity, pH, Leukocytes, Transitional epithelial cells, Mucus \\
\hline 7 & $\begin{array}{l}\text { Skin allergy test(pollen } \\
\text { allergens) }\end{array}$ & $\begin{array}{l}\text { Chenopodium, Sagebrush, Birch, Timothy, Cock's-foot, Elytrigia, Ryegrass, Alder, Sunflower, } \\
\text { Fescue grass, Walnut, Rye, Linden, Nettle, Dandelion, Sump weed, Plantain, Foxtail, Ragweed, } \\
\text { Chestnut, Cypress, Maple }\end{array}$ \\
\hline 8 & $\begin{array}{l}\text { Skin allergy test(household } \\
\text { allergens) }\end{array}$ & Pillow feather, Domestic dust, Rabbit hair, Cat hair, Dog hair, Sheep wool, Daphnia \\
\hline 9 & Food allergy test & $\begin{array}{l}\text { Carp fish, Pollack fish, Egg white, Milk, Apple, Raspberries, Beetroot, Cabbage, Beef, Lemon, Pork, } \\
\text { Banana, Watermelon, Orange, Chicken, Tangerine, Cocoa, Soybeans, Black tea, Grape, Tomato, Rice } \\
\text { groats, Buckwheat grits, Beans, Wheat groats, Oat grits, Corn grits, Rye grits }\end{array}$ \\
\hline 10 & Ig E & Serum immunoglobulin E \\
\hline 11 & Spirogram & $\begin{array}{l}\text { VC, FVC, PEF, FEF(MEF) 25\%, FEF(MEF) 50\%, FEF(MEF) 75\%, FEV 25-75\%, FEV1, FEV/FVC \%, } \\
\text { MVV. }\end{array}$ \\
\hline 12 & Immunological status & 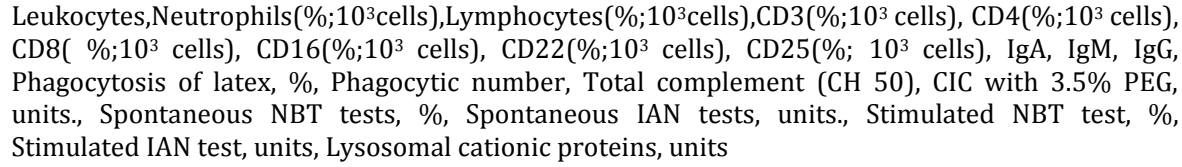 \\
\hline 13 & TSLP & The level of serum thymic stromal lymphopoietin \\
\hline 14 & Age & Age of the examined children from 6 to 17 years \\
\hline 15 & Gender & Surveyed 56 boys and 14 girls \\
\hline
\end{tabular}

A large number of factors determining a specific feature are coded with a value of 0 or 1 . In the above analysis, there are also factors that can take on values corresponding to several states. Thus, for example, the factor [8.Pillow feather] characterizes four degrees of severity of the skin allergy test, each of its states is coded in the order of increasing. The number in front of the factor name determines the category the factor belongs to.
Factors that occurred as a result of clinical trials in no more than two patients were excluded from the analysis of the raw data. The list of excluded factors is presented in Table 2 . The factors excluded are expected to have a small effect on the data analysis result and may not be considered. This allowed to reduce the total number of factors to be analyzed by 10\%.

Table: 2 . List of excluded factors

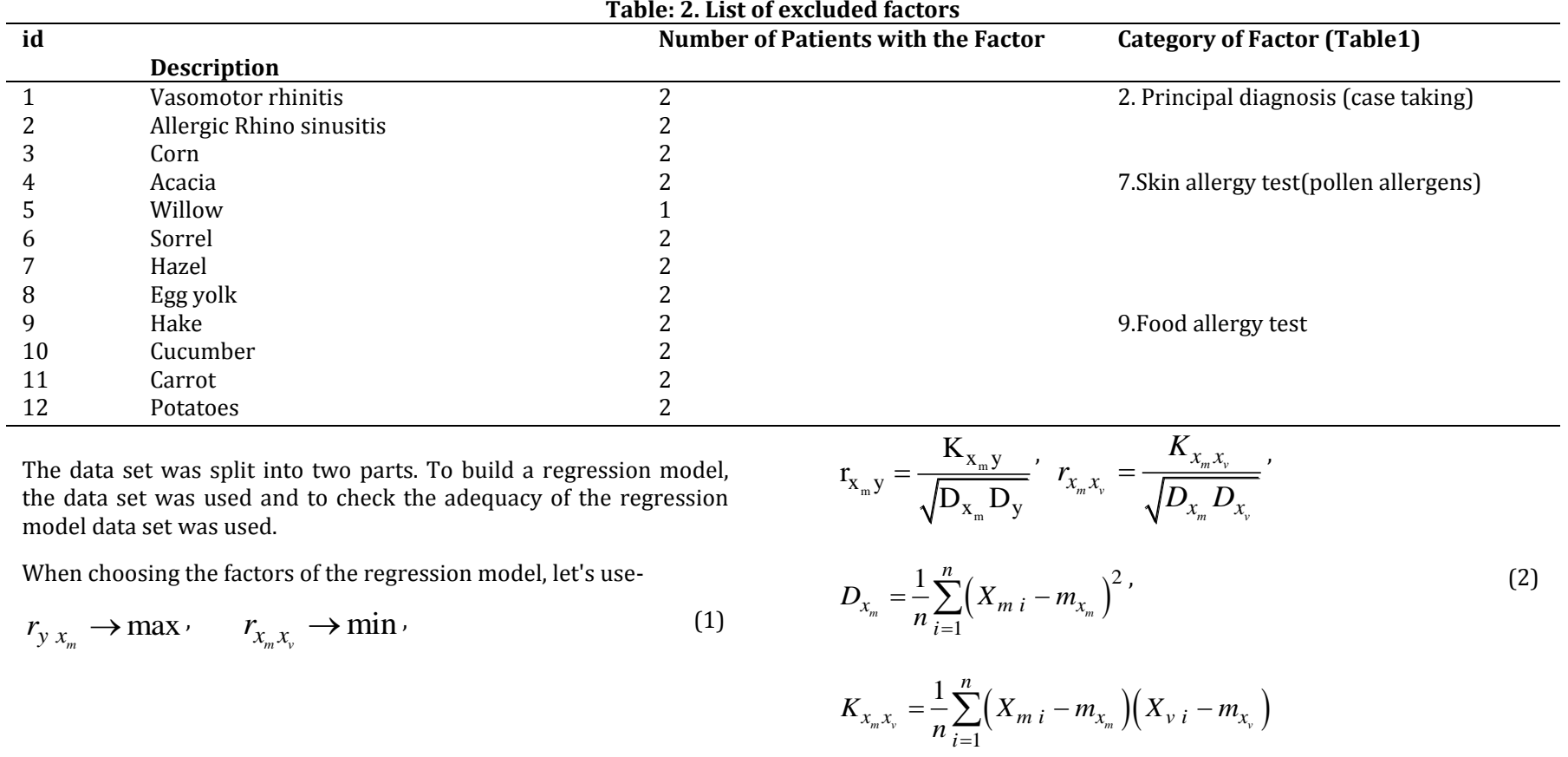


' $m_{x_{m}}=\frac{1}{n} \sum_{i=1}^{n} X_{m i}{ }^{\prime} \quad m_{y}=\frac{1}{n} \sum_{i=1}^{n} Y_{i}{ }^{\prime}$

where $r_{y x_{m}}$ is the coefficient of correlation between the observed factor $Y$ and the regressor $X_{m} ; r_{x_{m} x_{v}}$ is correlation coefficient between regressor $X_{m}$ and regressor $X_{v} ; \mathrm{K}_{\mathrm{x}_{\mathrm{m}} \mathrm{y}}$ is covariance between the observed factor $Y$ and the regressor $X_{m} ; K_{x_{m} x_{v}}$ is covariance between regressor $X_{m}$ and regressor $X_{v} ; \mathrm{D}_{\mathrm{y}}$ is variance for the observed factor $Y ; \mathrm{D}_{\mathrm{x}_{\mathrm{m}}}$ is variance for the regressor $X_{m} ; \mathrm{m}_{\mathrm{y}}, \mathrm{m}_{\mathrm{x}_{\mathrm{m}}}$ are means for the observed value $Y$ and the regressor $X_{m}$.

The set of factors in accordance with criterion (1) is shown in Table 3.

Table: 3 Factors

\begin{tabular}{|c|c|c|c|c|c|c|c|}
\hline & $\begin{array}{l}\text { 2.Atopic } \\
\text { dermatitis }\end{array}$ & $\begin{array}{l}\text { 4.Bronchial } \\
\text { asthma in } \\
\text { relatives of } \\
\text { second } \\
\text { generation }\end{array}$ & $\begin{array}{l}\text { 2.Allergic } \\
\text { rhinitis }\end{array}$ & $\begin{array}{l}\text { 8.Sheep } \\
\text { wool }\end{array}$ & $\begin{array}{l}\text { 8.Domestic } \\
\text { dust }\end{array}$ & $\begin{array}{l}\text { 8.Rabbit } \\
\text { hair }\end{array}$ & $\begin{array}{l}\text { 8.Pillow } \\
\text { feather }\end{array}$ \\
\hline 2.Atopic dermatitis & - & $-0,0778$ & 0,1147 & 0,1969 & 0,131 & 0,2282 & 0,666 \\
\hline $\begin{array}{l}\text { 4.Bronchial asthma in relatives } \\
\text { of second generation }\end{array}$ & $-0,0778$ & - & 0,078 & 0,1338 & 0,2677 & 0,0077 & 0,2606 \\
\hline 2.Allergic rhinitis & 0,1147 & 0,078 & - & $-0,0414$ & 0,1835 & 0,1266 & 0,0193 \\
\hline 8.Sheep wool & 0,1969 & 0,1338 & $-0,0414$ & - & 0,1636 & 0,3102 & 0,2804 \\
\hline 8.Domestic dust & 0,131 & 0,2677 & 0,1835 & 0,1636 & - & $-0,0391$ & 0,2025 \\
\hline 8.Rabbit hair & $-0,2282$ & 0,0077 & 0,1266 & 0,3102 & $-0,0391$ & - & 0,084 \\
\hline 8.Pillow feather & $-0,666$ & 0,2606 & 0,0193 & 0,2804 & 0,2025 & 0,084 & - \\
\hline Severe & 0,4336 & 0,3024 & 0,31 & 0,3245 & 0,3206 & 0,2394 & 0,3437 \\
\hline
\end{tabular}

An increase in the absolute value of the covariance

The criterion $r_{y x_{m}} \rightarrow \max$ is determined for the observed value

[1.Severe persistent] and the regressor. According to the first

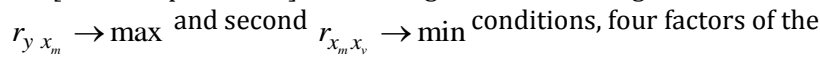
model are selected:[2.Allergic rhinitis ], [8.Sheep wool ], [8.Rabbit hair], [4.Bronchial asthma in relatives of second generation].

The regressors the absence of a connection with the explained factor is assumed for are presented in Table 4. For these factors, the correlation coefficient tends to zero $r_{y x} \rightarrow 0$

Table: 4. Regressors assumed as not having connection with the explained factor.

\begin{tabular}{|c|c|c|c|c|}
\hline № & Рeгресcop, $\mathrm{x}_{1}$ & № & \multicolumn{2}{|c|}{ Регресcop, $\mathrm{x}_{1}$} \\
\hline 1. & 9.Blacktea & & 9. & $\begin{array}{l}\text { 6.Specific } \\
\text { gravity }\end{array}$ \\
\hline 2. & 6.Appearance & & 10. & 9.Apple \\
\hline 3. & 7.Walnut & & 11. & 7.Sunflower \\
\hline 4. & otalcomplement (CH 50) & & 12. & $\begin{array}{l}\text { 6.Transitional } \\
\text { epithelial } \\
\text { cells }\end{array}$ \\
\hline 5. & 7.Sagebrush & & 13. & 12.IgA \\
\hline 6. & 12.Lymphocytes, $10 * 3 \mathrm{cel}$ & & 14. & 8.Daphnia \\
\hline 7. & 2.Defiection of nasal sept & & 15. & $\begin{array}{l}\text { 5.Segmented } \\
\text { neutrophils, } \\
\%\end{array}$ \\
\hline 8. & $\begin{array}{l}\text { 4.Bronchial asthma in } \\
\text { mother }\end{array}$ & & & \\
\hline
\end{tabular}

\section{One-parameter linear model}

The linear pair wise regression model for the observed value $Y$ and the regressor ${ }_{X_{m}}$ has the form

$\mathrm{y}=\mathrm{a}+\mathrm{b}_{\mathrm{m}} \mathrm{x}_{\mathrm{m}}$,

$\mathrm{a}=\mathrm{m}_{\mathrm{y}}-\mathrm{m}_{\mathrm{x}_{\mathrm{m}}} \mathrm{b}_{\mathrm{m}}, \quad \mathrm{b}_{\mathrm{m}}=\frac{\mathrm{K}_{\mathrm{x}_{\mathrm{m}} \mathrm{x}_{\mathrm{v}}}}{\mathrm{D}_{\mathrm{x}_{\mathrm{m}}}}$,

With the values of the coefficients $\mathrm{a}^{\text {и }} \mathrm{b}_{\mathrm{m}}$, which are determined taking into account formulas (2), (3). coefficient leads to an increase in the relationship between the parameters $Y$ и $X_{m}$. Let's go to new variables

$\xi_{\mathrm{m}}=\frac{\mathrm{x}_{\mathrm{m}}-\mathrm{m}_{\mathrm{x}_{\mathrm{m}}}}{\sqrt{\mathrm{D}_{\mathrm{x}_{\mathrm{m}}}}} \eta=\frac{\mathrm{y}_{1}-\mathrm{m}_{\mathrm{y}}}{\sqrt{\mathrm{D}_{\mathrm{y}}}}$,

$\sigma_{\mathrm{x}_{\mathrm{m}}}=\sqrt{\mathrm{D}_{\mathrm{x}_{\mathrm{m}}}}, \quad \sigma_{\mathrm{y}}=\sqrt{\mathrm{D}_{\mathrm{y}}}$,

Then the dependence between the parameters can be represented in a simpler form

$\eta=\mathrm{r}_{\mathrm{y} \mathrm{x}_{\mathrm{m}}} \xi_{\mathrm{m}}, \quad-1 \leq \mathrm{r}_{\mathrm{y}_{\mathrm{m}}} \leq 1$,

Where $r_{y} x_{m}$ is the correlation coefficient between the parameters $Y$ и $X_{m}$, corresponds to the degree of linear dependence of the parameters themselves; $\sigma_{\mathrm{x}_{\mathrm{m}}}, \sigma_{\mathrm{y}}$ are standard deviations. The magnitude of the value $r_{y x_{m}}$ sets the degree of tightness of the linear relationship.

\section{Two-parameter linear model}

The two-parameter linear regression model for the observed value $Y$ and two regressors $X_{m}, X_{v}$ has the form

$\mathrm{y}=\mathrm{a}+\mathrm{b}_{\mathrm{m}} \mathrm{x}_{\mathrm{m}}+\mathrm{b}_{\mathrm{v}} \mathrm{x}_{\mathrm{v}}$.

In consideration of

$$
\begin{aligned}
& \sum_{\mathrm{i}=1}^{\mathrm{N}} \mathrm{y}_{\mathrm{i}}=\mathrm{a} \sum_{\mathrm{i}=1}^{\mathrm{N}} 1+\mathrm{b}_{\mathrm{m}} \sum_{\mathrm{i}=1}^{\mathrm{N}} \mathrm{x}_{\mathrm{mi}}+\mathrm{b}_{\mathrm{v}} \sum_{\mathrm{i}=1}^{\mathrm{N}} \mathrm{x}_{\mathrm{vi}}{ }^{\prime} \\
& \mathrm{m}_{\mathrm{y}}=\mathrm{a}+\mathrm{b}_{\mathrm{m}} \mathrm{m}_{\mathrm{x}_{\mathrm{m}}}+\mathrm{b}_{\mathrm{v}} \mathrm{m}_{\mathrm{x}_{\mathrm{v}}},
\end{aligned}
$$

And using notation (6), let's write the equations of the twoparameter linear model in the dimensionless form

$\eta=\beta_{\mathrm{m}} \cdot \xi_{\mathrm{m}}+\beta_{\mathrm{v}} \cdot \xi_{\mathrm{v}}$, 
$\beta_{\mathrm{m}}=\mathrm{b}_{\mathrm{m}} \frac{\sqrt{\mathrm{D}_{\mathrm{x}_{\mathrm{m}}}}}{\sqrt{\mathrm{D}_{\mathrm{y}}}}, \beta_{\mathrm{v}}=\mathrm{b}_{\mathrm{v}} \frac{\sqrt{\mathrm{D}_{\mathrm{x}_{\mathrm{m}}}}}{\sqrt{\mathrm{D}_{\mathrm{y}}}}$.

Coefficients $\beta_{\mathrm{m}}$ and $\beta_{\mathrm{v}}$ are determined from the system of equations

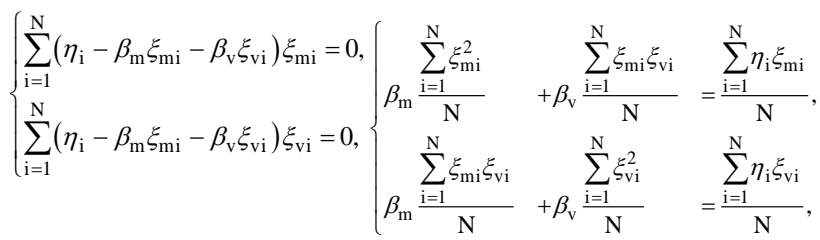

Which can be represented as

$\left\{\begin{array}{lll}\beta_{\mathrm{m}} & +\beta_{\mathrm{v}} \cdot \mathrm{r}_{\mathrm{x}_{\mathrm{m}} \mathrm{x}_{\mathrm{v}}} & =\mathrm{r}_{\mathrm{y}_{\mathrm{m}}}, \\ \beta_{\mathrm{m}} \cdot \mathrm{r}_{\mathrm{x}_{\mathrm{m}} \mathrm{x}_{\mathrm{v}}}+\beta_{\mathrm{v}} & =\mathrm{r}_{\mathrm{y} \mathrm{x}_{\mathrm{v}}}\end{array}\right.$

Let us solve the system of equations (13) for the unknowns $\beta_{\mathrm{m}}, \beta_{\mathrm{v}}$ :

$\beta_{\mathrm{m}}=\frac{\mathrm{r}_{\mathrm{y} \mathrm{x}_{\mathrm{m}}}-\mathrm{r}_{\mathrm{y} \mathrm{x}_{\mathrm{v}}} \mathrm{r}_{\mathrm{x}_{\mathrm{m}} \mathrm{x}_{\mathrm{v}}}}{1-\left(\mathrm{r}_{\mathrm{x}_{\mathrm{m}} \mathrm{x}_{\mathrm{v}}}\right)^{2}} \quad \beta_{\mathrm{v}}=\frac{\mathrm{r}_{\mathrm{y}_{\mathrm{v}}}-\mathrm{r}_{\mathrm{y} \mathrm{x}_{\mathrm{m}}} \mathrm{r}_{\mathrm{x}_{\mathrm{m}} \mathrm{x}_{\mathrm{v}}}}{1-\left(\mathrm{r}_{\mathrm{x}_{\mathrm{m}} \mathrm{x}_{\mathrm{v}}}\right)^{2}}$

Coefficients $\mathrm{a}, \mathrm{b}_{\mathrm{m}}, \mathrm{b}_{\mathrm{v}}$ are determined from expressions (10), (12)

$b_{m}=\sqrt{\frac{D_{x_{m}}}{D_{y}}} \frac{r_{y_{x_{m}}}-r_{y_{x_{v}}} r_{x_{m} x_{v}}{ }^{\prime} b_{v}=\sqrt{\frac{D_{x_{v}}}{D_{y}}} \frac{r_{y_{x}}-\left(r_{x_{m} x_{v}}\right)^{2}}{1-\left(r_{x_{m} x_{m}}\right)^{2}} r_{x_{m} x_{v}}}{1}$

$$
\mathrm{a}=\mathrm{m}_{\mathrm{y}}-\mathrm{b}_{\mathrm{m}} \mathrm{m}_{\mathrm{x}_{\mathrm{m}}}-\mathrm{b}_{\mathrm{v}} \mathrm{m}_{\mathrm{x}_{\mathrm{v}}} \text {. }
$$

Coefficients $a, b_{m}, b_{v}$ determine the equation of a two-parameter linear model, presented in dimensional form. Coefficients $\beta_{\mathrm{m}}$ and $\beta_{\mathrm{v}}$ are used for a two-parameter linear model, the parameters of which are presented in dimensionless form.

Linear two-factor equations (8) for diagnosing the severity of bronchial asthma disease are shown in Fig. 1 - Fig. 6.

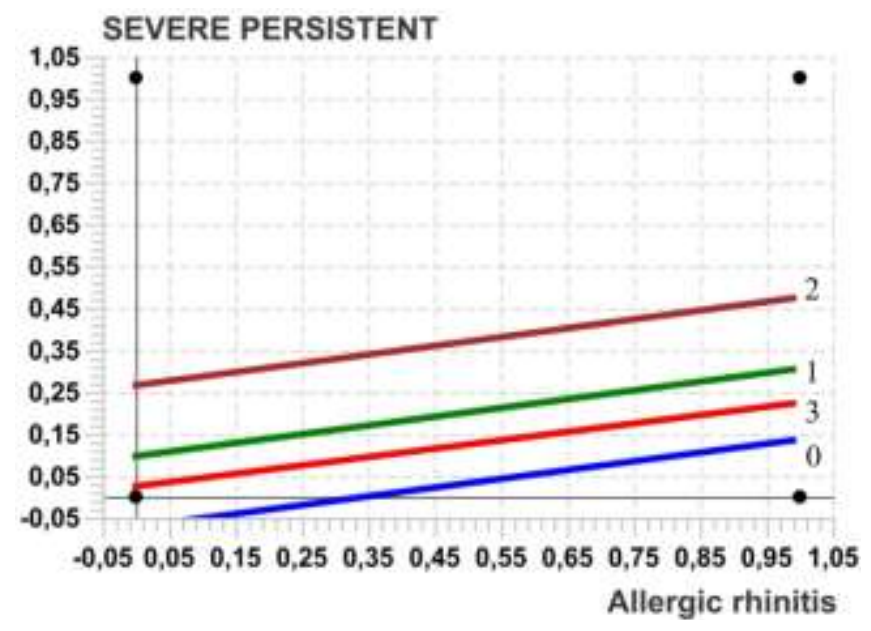

Fig. 1: Two-parameter model $\mathrm{y}=-0,07+0,21 \mathrm{x}_{1}+0,17 \mathrm{x}_{2}$

, $\mathrm{x}_{2}=\{0 ; 1 ; 2\}$ (Table 2), one-parameter model

$\mathrm{y}=0,025+0,2 \mathrm{x}_{1}, \mathrm{x}_{2}=3$ (Table: 1 )
SEVERE PERSISTENT

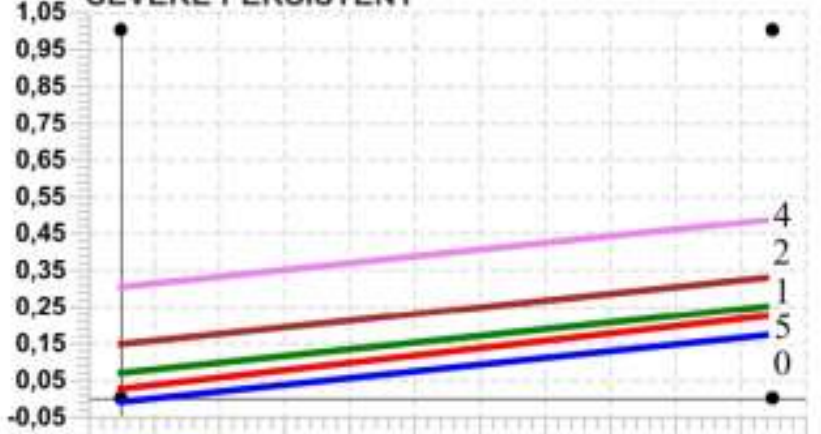

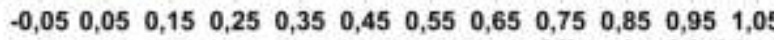

Allergic rhinitis

Fig. 2: Two-parameter model $\mathrm{y}=-0,01+0,18 \mathrm{x}_{1}+0,08 \mathrm{x}_{2}$,

$\mathrm{x}_{2}=\{0 ; 1 ; 2 ; 4\}$ (Table 2), one-parameter model

$$
\mathrm{y}=0,025+0,2 \mathrm{x}_{1}, \mathrm{x}_{2}=5 \text { (Table: } \mathbf{1} \text { ) }
$$

\section{SEVERE PERSISTENT}

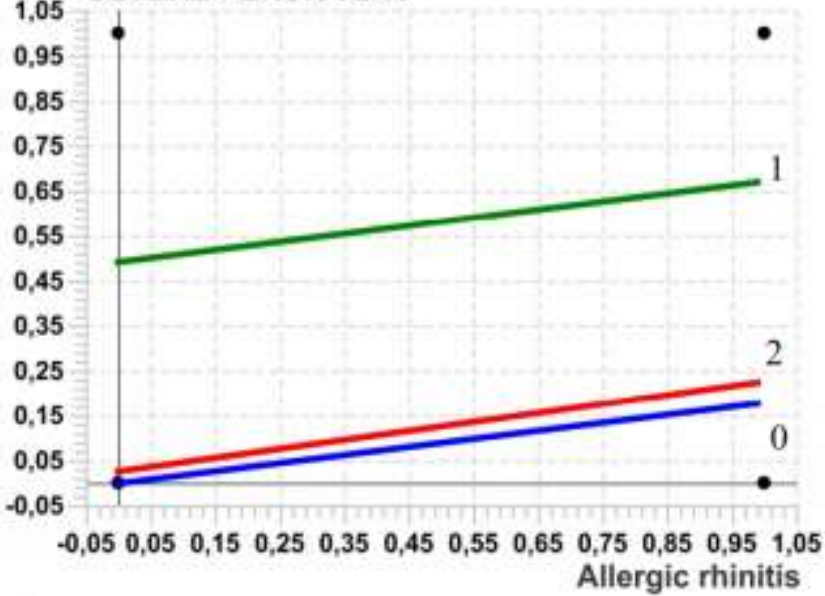

Fig. 3: Two-parameter model $y=0,18 x_{1}+0,49 x_{2}$,

$$
\begin{aligned}
x_{2} & =\{0 ; 1\} \text { (Table 2), one-parameter model } \\
y & =0,025+0,2 x_{1}, x_{2}=2 \text { (Table: } 1 \text { ) }
\end{aligned}
$$

\section{SEVERE PERSISTENT}

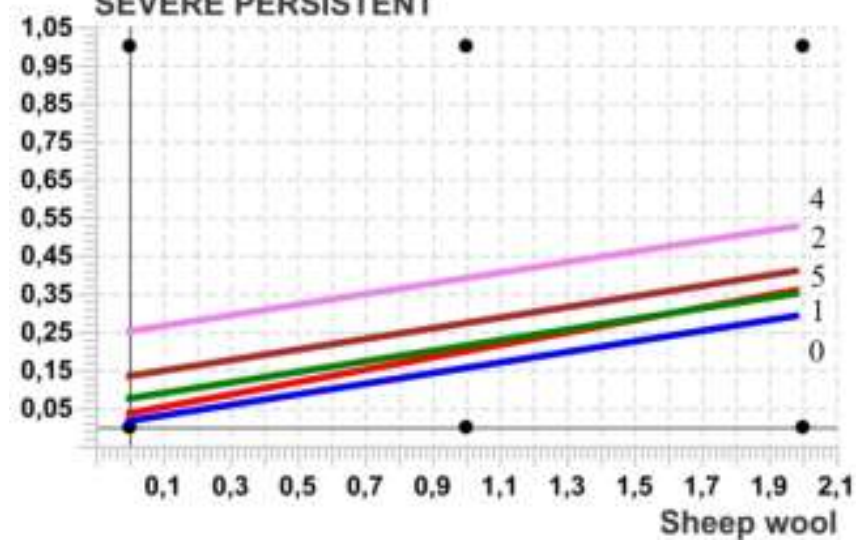

Fig. 4: Two-parameter model $y=0,02+0,14 x_{1}+0,06 x_{2}$,

$$
\begin{aligned}
x_{2} & =\{0 ; 1 ; 2 ; 4\} \text { (Table 2), one-parameter model } \\
y & \left.=0,0361+0,1626 x_{1}, x_{2}=5 \text { (Table: } 1\right)
\end{aligned}
$$




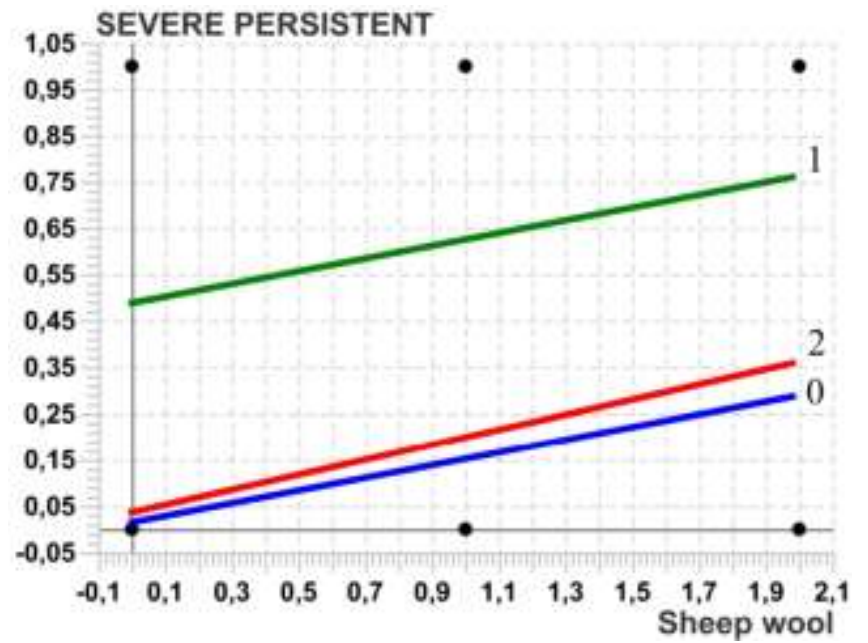

Fig. 5: Two-parameter model $y=0,01+0,14 x_{1}+0,47 x_{2}$,

$$
\begin{aligned}
& \mathrm{x}_{2}=\{0 ; 1 ;\} \text { (Table 2), one-parameter model } \\
& \mathrm{y}=0,0361+0,1626 \mathrm{x}_{1}, \mathrm{x}_{2}=2 \text { (Table: } 1 \text { ) }
\end{aligned}
$$

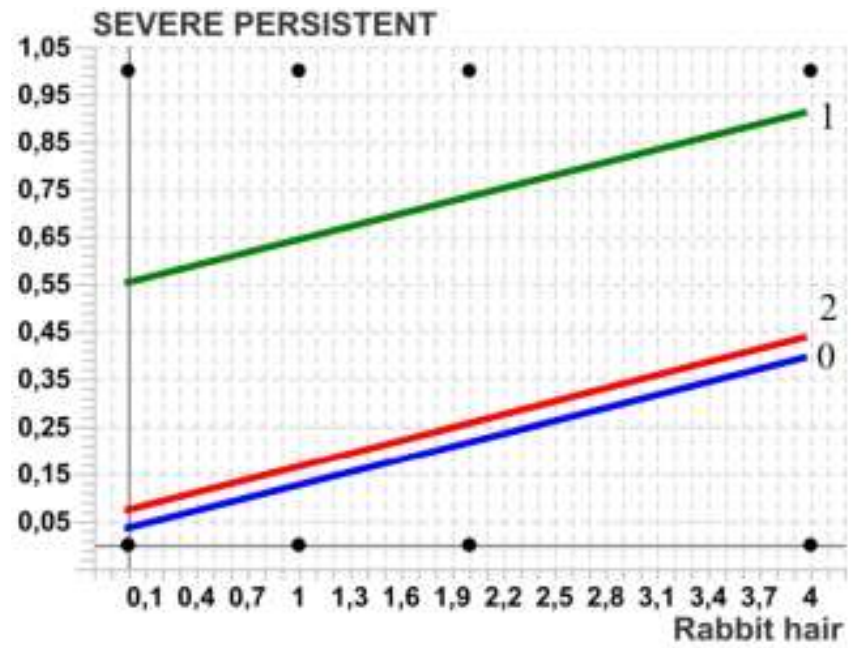

Fig. 6: Two-parameter model $y=0,04+0,09 x_{1}+0,52 x_{2}$,

$$
\begin{aligned}
& \mathrm{x}_{2}=\{0 ; 1 ;\} \text { (Table 2), one-parameter model } \\
& \mathrm{y}=0,0735+0,0916 \mathrm{x}_{1}, \mathrm{x}_{2}=2 \text { (Table: 1) }
\end{aligned}
$$

\section{The approximate two-parameter linear model}

It was discussed above that the correlation coefficient $r_{x_{m}} x_{v}$ between the model regressors is small compared to 1.0: $r_{x_{m} x_{v}}<<1$.

When choosing the factors of the model determined by condition (4), it is also assumed that

$$
r_{x_{m} x_{v}}<r_{y x_{v}} \quad r_{x_{m} x_{v}}<r_{y x_{m}} .
$$

Taking this into account, the expression for the coefficients $\beta_{\mathrm{m}}$ and $\beta_{\mathrm{v}}$ (14) can be represented as

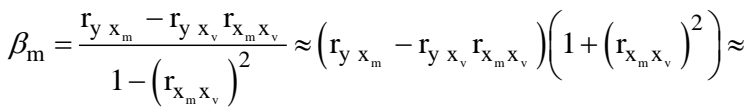

$$
\begin{aligned}
& \approx \mathrm{r}_{\mathrm{y}_{\mathrm{m}}}-\mathrm{r}_{\mathrm{y} \mathrm{x}_{\mathrm{v}}} \mathrm{r}_{\mathrm{x}_{\mathrm{m}} \mathrm{x}_{\mathrm{v}}} \approx \mathrm{r}_{\mathrm{y} \mathrm{x}_{\mathrm{m}}}+0\left(\mathrm{r}_{\mathrm{x}_{\mathrm{m}} \mathrm{x}_{\mathrm{v}}}\right),
\end{aligned}
$$

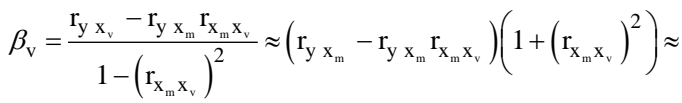

$$
\begin{aligned}
& \approx \mathrm{r}_{\mathrm{y}_{\mathrm{m}}}-\mathrm{r}_{\mathrm{yx}_{\mathrm{m}}} \mathrm{r}_{\mathrm{x}_{\mathrm{m}} \mathrm{x}_{\mathrm{v}}} \approx \mathrm{r}_{\mathrm{y}_{\mathrm{v}}}+0\left(\mathrm{r}_{\mathrm{x}_{\mathrm{m}} \mathrm{x}_{\mathrm{v}}}\right) .
\end{aligned}
$$

Substituting the obtained expressions for the coefficients into equation (11),let's obtain an approximate two-parameter model for assessing the severity

$$
\eta=\mathrm{r}_{\mathrm{y} \mathrm{x}_{\mathrm{m}}} \cdot \xi_{\mathrm{m}}+\mathrm{r}_{\mathrm{y}_{\mathrm{v}}} \cdot \xi_{\mathrm{v}}+0\left(\mathrm{r}_{\mathrm{x}_{\mathrm{m}} \mathrm{x}_{\mathrm{v}}}\right) .
$$

The approximate two-parameter model (19) is a superposition of two one-parameter models (7). The error in calculating the coefficients $\beta_{\mathrm{m}}$ and $\beta_{\mathrm{v}}$ (14) is determined by the magnitude of the correlation between the regressors of the model $0\left(\mathrm{r}_{\mathrm{x}_{\mathrm{m}} \mathrm{x}_{\mathrm{v}}}\right)$.

\section{RESULTS AND DISCUSSION}

One of significant prognostic factors of severe BAis infantile sensibilization and sensibilization to a big number of allergens [24]. Numerous studies of allergens, such as house dust mites, mold and cat hair, have proved their role in asthma triggering mechanism in children $[25,26]$. The atopic outcome risk is the highest in childhood, while it also increases among grown-ups. The result of allergen affecting significantly depends on the allergen dose and type, its exposure time and child's frailty [27, 29].Asthma progress is more frequently observed in children suffering from atopic dermatitis or allergic rhinitis [30-32]. The study of Corren J. has proved that treatment of allergic rhinitis decreases the risk of severe bronchial asthma [33].

One-parameter linear regression models are the most commonly used in bronchial asthma severity analyzing during preliminary experimental data processing. Their use can be explained by simplicity of the model building. One-parameter linear model reveals dependence of one variable (interpretable variable) on another variable (regressor) with a linear connection function. Oneparameter linear regression coefficient $b_{m}$ (5) is an important model criterion. This coefficient defines the rate of a dependent variable change on the given factor (regressor) with fixed values of the rest of the factors; it is proportional to the correlation coefficient between the observed value of $Y$ and the regressor of $X_{m}$ (7),

$m=1 . . M$. One-parameter linear regression model allows setting up qualitative characteristics at the preliminary stage of analysis. However, most often during a preliminary study, a seeker has to get an approximate estimation of an interpretable variable dependence on several factors in order to specify qualitative dependences among the model factors. Models of multiple regression are used to specify the analysis. However, even a building of two- or three-parameter linear regression models requires either massive calculations or specialized software. This is due to the fact that the total amount of two-parameter models is proportional to $\sim M^{2}$, and the total amount of three-parameter models is proportional to $\sim M^{3}$. The essential feature of bronchial asthma severity analysis is connected with the fact that the observed value depends on a large amount of factors $M \sim 100$. Correlation connection between the observed value and the regressor is weak for the most of regressors and the connection between regressors themselves is almost absent (Table 3)[19]. This is exactly what allows us to simplify a building of approximate two- or three-parameter linear regression models significantly. Whereby, as illustrated above, an error appearing when a proximate regression model is replaced with an approximate one can be defined as a value which is proportional to the correlation coefficient of the model regressors $0\left(r_{x_{m} x_{v}}\right)$. 
A comparative analysis of approximate model determined by coefficients (14) and an approximate model determined by coefficients (17), (18) for regressors with maximum values of the correlation coefficient of $r_{y x_{m}}$ (Table 3) is presented in Table 5.
Table 5 shows the form of an approximate and proximate twoparameter model as well as error estimation for an approximate model.

Table: 5. Estimation of an approximate linear regression model

\begin{tabular}{|c|c|c|c|c|}
\hline $\begin{array}{l}\text { dimensionless } \\
\text { pairwise } \\
\text { regression } \\
\text { model for } Z_{1}\end{array}$ & $\begin{array}{l}\text { dimensionless } \\
\text { pairwise } \\
\text { regression model } \\
\quad \text { for } \mathrm{Z}_{2}\end{array}$ & $\begin{array}{c}\text { two- } \\
\text { parameterdimensionless } \\
\text { model }\end{array}$ & $\begin{array}{l}\text { approximate two- } \\
\text { parameter dimensionless } \\
\text { model } \\
\mathrm{g}_{2 \mathrm{appx}}=\mathrm{g}_{11}+\mathrm{g}_{12}\end{array}$ & $\begin{array}{l}\text { approximate model error } \\
\Delta \mathrm{g}=\mathrm{g}_{2}-\mathrm{g}_{2 \mathrm{new}}\end{array}$ \\
\hline & $\begin{array}{l}\text { Sheep wool } \\
\mathrm{g}_{12}=0,3245 \mathrm{z}_{2}\end{array}$ & $\mathrm{~g}_{2}=0,32 \mathrm{z}_{1}+0,34 \mathrm{z}_{2}$ & $\mathrm{~g}_{2}=0,31 \mathrm{z}_{1}+0,317 \mathrm{z}_{2}$ & $\Delta \mathrm{g}=0,01 \mathrm{z}_{1}+0,015 \mathrm{z}_{2}$ \\
\hline $\begin{array}{l}\text { Allergic rhinitis } \\
\mathrm{g}_{11}=0,31 \mathrm{z}_{1}\end{array}$ & $\begin{array}{l}\text { Rabbit hair } \\
\mathrm{g}_{12}=0,2394 \mathrm{z}_{2}\end{array}$ & $\mathrm{~g}_{2}=0,28 \mathrm{z}_{1}+0,20 \mathrm{z}_{2}$ & $\mathrm{~g}_{2}=0,31 \mathrm{z}_{1}+0,2394 \mathrm{z}_{2}$ & $\Delta \mathrm{g}=-0,03 \mathrm{z}_{1}+0,039 \mathrm{z}_{2}$ \\
\hline & $\begin{array}{l}\text { Bronchial asthma } \\
\text { in relatives } \\
\text { of second } \\
\text { generation } \\
\mathrm{g}_{12}=0,3024 \mathrm{z}_{2}\end{array}$ & $\mathrm{~g}_{2}=0,27 \mathrm{z}_{1}+0,39 \mathrm{z}_{2}$ & $\mathrm{~g}_{2}=0,31 \mathrm{z}_{1}+0,3024 \mathrm{z}_{2}$ & $\Delta \mathrm{g}=-0,04 \mathrm{z}_{1}+0,087 \mathrm{z}_{2}$ \\
\hline Sheep & $\begin{array}{l}\text { Rabbit hair } \\
\mathrm{g}_{12}=0,2394 \mathrm{z}_{2}\end{array}$ & $\mathrm{~g}_{2}=0,28 \mathrm{z}_{1}+0,15 \mathrm{z}_{2}$ & $\mathrm{~g}_{2}=0,324 \mathrm{z}_{1}+0,239 \mathrm{z}_{2}$ & $\Delta \mathrm{g}=-0,04 \mathrm{z}_{1}-0,079 \mathrm{z}_{2}$ \\
\hline $\mathrm{g}_{11}=0,3245 \mathrm{z}_{2}$ & $\begin{array}{l}\text { Bronchial asthma } \\
\text { in relatives } \\
\text { of second } \\
\text { generation } \\
\mathrm{g}_{12}=0,3024 \mathrm{z}_{2}\end{array}$ & $\mathrm{~g}_{2}=0,27 \mathrm{z}_{1}+0,38 \mathrm{z}_{2}$ & $\mathrm{~g}_{2}=0,324 \mathrm{z}_{1}+0,302 \mathrm{z}_{2}$ & $\Delta \mathrm{g}=-0,05 \mathrm{z}_{1}+0,078 \mathrm{z}_{2}$ \\
\hline $\begin{array}{l}\text { Rabbit hair } \\
\mathrm{g}_{11}=0,2394 \mathrm{z}_{2}\end{array}$ & $\begin{array}{l}\text { Bronchial asthma } \\
\text { in relatives } \\
\text { of second } \\
\text { generation } \\
\mathrm{g}_{12}=0,3024 \mathrm{z}_{2}\end{array}$ & $\mathrm{~g}_{2}=0,24 \mathrm{z}_{1}+0,41 \mathrm{z}_{2}$ & $\mathrm{~g}_{2}=0,24 \mathrm{z}_{1}+0,3024 \mathrm{z}_{2}$ & $\Delta g=0,1016 z_{2}$ \\
\hline
\end{tabular}

The results of the comparative analysis clearly demonstrate that models in a dimensionless and a dimensional form for the studied replacing a proximate model with an approximate one leads to an error of $3 \%$ to $10 \%$, which is a fairly good result. Two-parameter models in a dimensionless and
regressors are shown in Table 6.

Table: 6 Two-parameter models

\begin{tabular}{clllc}
\hline № & \multicolumn{1}{c}{ regressor $\mathrm{z}_{1}$} & \multicolumn{1}{c}{ regressor $\mathrm{Z}_{2}$} & $\begin{array}{c}\text { Two-parameter } \\
\text { dimensionless model }\end{array}$ & two-parameter model \\
\hline 1 & Allergic rhinitis & Sheep wool & $\mathrm{g}_{2}=0,32 \mathrm{z}_{1}+0,34 \mathrm{z}_{2}$ & $\mathrm{y}=-0,07+0,21 \mathrm{x}_{1}+0,17 \mathrm{x}_{2}$ \\
2 & Allergic rhinitis & Rabbit hair & $\mathrm{g}_{2}=0,28 \mathrm{z}_{1}+0,20 \mathrm{z}_{2}$ & $\mathrm{y}=-0,01+0,18 \mathrm{x}_{1}+0,08 \mathrm{x}_{2}$ \\
3 & Allergic rhinitis & $\begin{array}{l}\text { Bronchial asthma in relatives } \\
\text { of second generation }\end{array}$ & $\mathrm{g}_{2}=0,27 \mathrm{z}_{1}+0,39 \mathrm{z}_{2}$ & $\mathrm{y}=0,18 \mathrm{x}_{1}+0,49 \mathrm{x}_{2}$ \\
4 & Sheepwool & Rabbit hair & $\mathrm{g}_{2}=0,28 \mathrm{z}_{1}+0,15 \mathrm{z}_{2}$ & $\mathrm{y}=0,02+0,14 \mathrm{x}_{1}+0,06 \mathrm{x}_{2}$ \\
5 & Sheepwool & $\begin{array}{l}\text { Bronchial asthma in relatives } \\
\text { of second generation } \\
\text { Bronchial asthma in relatives } \\
\text { of second generation }\end{array}$ & $\mathrm{g}_{2}=0,27 \mathrm{z}_{1}+0,38 \mathrm{z}_{2}$ & $\mathrm{y}=0,01+0,14 \mathrm{x}_{1}+0,47 \mathrm{x}_{2}$ \\
6 & Rabbit hair & $\mathrm{g}_{2}=0,24 \mathrm{z}_{1}+0,41 \mathrm{z}_{2}$ & $\mathrm{y}=0,04+0,09 \mathrm{x}_{1}+0,52 \mathrm{x}_{2}$ \\
\hline
\end{tabular}

One-parameter linear regression models that were used to build an approximate two-parameter model are presented in Table 7.

As well as in the case of two-parameter models, one-parameter regression models are given both in a dimensionless form and in a dimensional form. The models are built for the factors defined in Table 3 .

It should be mentioned that for a limiting case when there is no connection between model regressors $r_{\mathrm{x}_{\mathrm{m}} \mathrm{x}_{\mathrm{v}}}=0$, the expression for an approximate model satisfies the expression defining the value of interpretable quantity for a proximate model completely (18).If a model contains regressors, then a high value correlation coefficient between them, replacing of proximate regression models with approximate ones, will lead to significant errors. That's why an estimation of correlation coefficients between model regressors is required before immediate application of the model-building method. Choice of the factors to be represented as model regressors has to follow the criterion (1). 
Table 7. One-parameter model

\begin{tabular}{|c|c|c|c|}
\hline № & regressor $Z_{1}$ & $\begin{array}{c}\text { Dimensionless one-parameter } \\
\text { model }\end{array}$ & one-parameter model \\
\hline 1 & Allergic rhinitis & $\mathrm{g}_{11}=0,31 \mathrm{z}_{1}$ & $\mathrm{y}=0,025+0,2 \mathrm{x}_{1}$ \\
\hline 2 & Sheep wool & $\mathrm{g}_{11}=0,3245 \mathrm{z}_{1}$ & $y=0,0361+0,1626 x_{1}$ \\
\hline 3 & Rabbit hair & $\mathrm{g}_{11}=0,2394 \mathrm{z}_{1}$ & $y=0,0735+0,0916 x_{1}$ \\
\hline 4 & $\begin{array}{lr}\text { Bronchial } & \text { asthma in } \\
\text { relatives } & \text { of second } \\
\text { generation } & \end{array}$ & $\mathrm{g}_{11}=0,3024 \mathrm{z}_{1}$ & $y=0,0863+0,5193 x_{1}$ \\
\hline
\end{tabular}

\section{CONCLUSIONS}

One-parameter linear regression models can be successfully used to build estimated two-parameter models that can be recommended for diagnosis of bronchial asthma severity. The suggested method of estimated two-parameter models has satisfactory accuracy allowing to use the suggested class of models to determine connections between the observed value and the factors under study.

The use of approximate models allows to simplify the analysis of experimental data defining severity of bronchial asthma during preliminary data processing. Approximate models help to hasten the process of the set of factors of regression model determination. Significant hastening is caused by the fact that one-parameter models can be replaced with two-parameter regression models during a preliminary stage of analyzing. Such a replacement for studies where an observed value depends on a large amount of factors helps to increase the data analysis accuracy. The accuracy of models replacement is higher, the smaller is the coefficient between the model regressors.

The suggested method of the approximate two-parameter linear regression model can be used for preliminary analyzing of different medical research where observed value depends on a large amount of loosely connected factors. In this case the level of complexity of two-parameter linear regression model building corresponds to the level of complexity of one-parameter linear regression model building.

Development of estimated three- and four-parameter models building for diagnosis of bronchial asthma severity is the perspective of further studies.

\section{REFERENCES}

1. Global Strategy for Asthma Management and Prevention. 2018. Available from: https://ginasthma.org/2018-ginareport-global-strategy-for-asthma-management-andprevention/ Global atlas of asthma.

2. Asthma. Who.int. 2019.Available from: http://www.who.int/ru/news-room/factsheets/detail/asthma/.

3. ISAAC - The International Study of Asthma and Allergies in Childhood. Isaac.auckland.ac.nz. 2019. Available from: http://isaac.auckland.ac.nz/.

4. Sritipsukho P, Satdhabudha A, Nanthapisal S. Effect of allergic rhinitis and asthma on the quality of life in young Thai adolescents. Asian Pac J Allergy Immunol. 2015;33(3):222-6.

5. Oliveira-Santos S, Motta-Franco J, Barreto I, Solé D, Gurgel R. Asthma in adolescents--Prevalence trends and associated factors in northeast Brazil. Allergollmmunopathol (Madr). 2015;43(5):429-35.

6. Montella S, Baraldi E, Cazzato S, Aralla R, Berardi M, Brunetti L et al. Severe asthma features in children: a case-control online survey. Ital J Pediatr. 2016; 42: 9.

7. Foster J, McDonald V, Guo M, Reddel H. "I have lost in every facet of my life": the hidden burden of severe asthma. European Respiratory Journal. 2017;50(3):1700765.

8. Fleming L, Murray C, Bansal A, Hashimoto S, Bisgaard H, Bush A et al. The burden of severe asthma in childhood and adolescence: results from the paediatric U-BIOPRED cohorts. European Respiratory Journal. 2015;46(5):1322-1333.

9. Andersson C, Adams A, Nagakumar P, Bossley C, Gupta A, De Vries $D$ et al. Intraepithelial neutrophils in pediatric severe asthma are associated with better lung function. J Allergy Clin Immunol. 2017;139:1819-1829.

10. Fajt M, Wenzel S. Asthma phenotypes and the use of biologic medications in asthma and allergic disease: The next steps toward personalized care. Journal of Allergy and Clinical Immunology. 2015;135(2):29-9310.

11. Salo P, Arbes S, Jaramillo R, Calatroni A, Weir C, Sever M et al Prevalence of allergic sensitization in the United States: Results from the National Health and Nutrition Examination Survey (NHANES) 2005-2006. Journal of Allergy and Clinical Immunology. 2014;134(2):350-359.

12. Gough H, Grabenhenrich L, Reich A, Eckers $\mathrm{N}$, Nitsche $\mathrm{O}$ Schramm D et al. Allergic multi morbidity of asthma, rhinitis and eczema over 20 years in the German birth cohort MAS. Pediatric Allergy and Immunology. 2015;26(5):431-437.

13. Garcia-Aymerich J, Benet M, Saeys Y, Pinart M, Basagaña X, Smit $\mathrm{H}$ et al. Phenotyping asthma, rhinitis and eczema in MeDALL population-based birth cohorts: an allergic comorbidity cluster. Allergy. 2015;70(8):973-984.

14. Pols D, Bohnen A, Nielen M, Korevaar J, Bindels P. Risks for co morbidity in children with atopic disorders: an observational study in Dutch general practices. BMJ Open. 2017; 7(11): e018091.

15. Pinart M, Benet M, Annesi-Maesano I, von Berg A, Berdel D, Carlsen K. Co morbidity of eczema, rhinitis, and asthma in IgEsensitised and non-IgE-sensitised children in MeDALL: a population-based cohort study. Lancet Respir Med. 2014;2(2):131-134.

16. Jacob L, Keil T, Kostev K. Comorbid disorders associated with asthma in children in Germany - National analysis of pediatric primary care data. Pediatr Allergy Immunol. 2016;27:861866.

17. Amin P, Levin L, Epstein T, Ryan P, LeMasters G, Khurana Hershey $G$ et al. Optimum Predictors of Childhood Asthma: Persistent Wheeze or the Asthma Predictive Index? The Journal of Allergy and Clinical Immunology: In Practice. 2014;2(6):709-715.e2.

18. Puranik S, Forno E, Bush A, Celedón J. Predicting severe asthma exacerbations in children.American Journal of Respiratory and Critical Care Medicine. 2017;195(7):854859.

19. Kozhyna 0, PihnastyiO. Data Structure of Clinical Research. Human Health \& Disease.2019;3(9):71-79.

20. Campo P, Rodríguez F, Sánchez-García S, Barranco P, Quirce S, Pérez-Francés $\mathrm{C}$ et al. Phenotypes and endotypes of uncontrolled severe asthma: new treatments. J InvestigAllergol Clin Immunol. 2013;23(2):76-88.

21. Lodge C, Zaloumis S, Lowe A, Gurrin L, Matheson M, Axelrad C et al. Early-life risk factors for childhood wheeze phenotypes in a high-risk birth cohort. J Pediatr. 2014;164:289-294.22.

22. Chung K, Wenzel S, Brozek J, Bush A, Castro M, Sterk P et al. International ERS/ATS guidelines on definition, evaluation and treatment of severe asthma. Eur Respir J. 2014;43:343373. 
23. Cook J, Beresford F, Fainardi V, Hall P, Housley G, Jamalzadeh A et al. Managing the paediatric patient with refractory asthma: a multidisciplinary approach. J. Asthma Allergy 2017; 10: $17-30$

24. Chong S, Chew. Epidemiology of allergic rhinitis and associated risk factors in Asia. World Allergy Organization Journal. 2018; 11:17.

25. Cazzoletti L, Ferrari M, Olivieri M, Verlato G, Antonicelli L, Bono $\mathrm{R}$ et al. The gender, age and risk factor distribution differs in self-reported allergic and non-allergic rhinitis: a cross-sectional population-based study. Allergy, Asthma \& Clinical Immunology. 2015;11(1).

26. Imhof K, Probst E, Seifert B, Regenass S, Schmid-Grendelmeier P. Ash pollen allergy: reliable detection of sensitization on the basis of IgE to Ole e 1. Allergo Journal International. 2014;23(3):78-83.

27. Hill D, Spergel J. The atopic march: critical evidence and clinical relevance. Ann Allergy Asthma Immunol. 2018; 120(2): 131-137.

28. Salo P, Arbes S, Jaramillo R, Calatroni A, Weir C, Sever M et al. Prevalence of allergic sensitization in the United States: Results from the National Health and Nutrition Examination
Survey (NHANES) 2005-2006. Journal of Allergy and Clinical Immunology. 2014;134(2):350-359.

29. Gough H, Grabenhenrich L, Reich A, Eckers N, Nitsche O, Schramm D et al. Allergic multimorbidity of asthma, rhinitis and eczema over 20 years in the German birth cohort MAS. Pediatric Allergy and Immunology. 2015;26(5):431-437.

30. Garcia-Aymerich J, Benet M, Saeys Y, Pinart M, Basagaña X, Smit $\mathrm{H}$ et al. Phenotyping asthma, rhinitis and eczema in MeDALL population-based birth cohorts: an allergic comorbidity cluster. Allergy. 2015;70(8):973-984.

31. Pols D, Bohnen A, Nielen M, Korevaar J, Bindels P. Risks for comorbidity in children with atopic disorders: an observational study in Dutch general practices. BMJ Open. 2017; 7(11): e018091.

32. Pinart M, Benet M, Annesi-Maesano I, von Berg A, Berdel D, Carlsen K. Comorbidity of eczema, rhinitis, and asthma in IgEsensitised and non-IgE-sensitised children in MeDALL: a population-based cohort study. Lancet Respir Med. 2014;2(2):131-134.

33. Corren J, Manning B.E., Thompson S.F., Strom B.L., Rhinitis therapy and the prevention of hospital care for asthma: a case-control study. J Allergy Clin Immunol. 2004; 113: 415419 